\title{
Valorisation of Cultural Heritage in Sustainable Tourism
}

\author{
KRISTINA AFRIĆ RAKITOVAC \\ Juraj Dobrila University of Pula, Croatia \\ kafric@unipu.hr \\ NATAŠA UROŠEVIĆ \\ Juraj Dobrila University of Pula, Croatia \\ natasa.urosevic@unipu.hr
}

\begin{abstract}
The paper reflects upon the models of development of cultural tourism in the city of Pula, Croatia, through cross-border international partnerships. Confronting global trends with local commitment to sustainable development, the authors set the hypothesis that heritage tourism, based on the strategic valorisation of unique cultural resources, could strengthen the identity and economy of the local community, create new jobs, increase the quality of life of local residents and the pleasure of visitors, improve the image and attract investors. The analysis of European examples of good practice indicated possible models of sustainable management and valorisation of specific categories of heritage, which could at the same time enhance the process of urban regeneration and social revitalization. The conducted research research indicated advantages of transnational cooperation in improving capacities for the sustainable use of the city's most valuable assets: the oldest historic city core on the eastern coast of the Adriatic, the Roman monuments including the Amphitheatre, the nearby Brioni islands and the legacy of the former Austria's main naval port with its powerful fortification system.
\end{abstract}

Key words: sustainable tourism, cultural heritage, cultural economy, cross-border international partnerships, Croatia https://doi.org/10.26493/1854-4231.12.199-215

\section{Introduction}

Turbulent global context, characterized by economic, social, environmental and political crisis, requires consideration of new models of management and sustainable use of limited, valuable local resources. Current strategic policy frameworks define priorities too in order to build national and regional competitive advantage by sustainable and innovative mobilisation of unique local resources. In this context, cultural heritage presents a capital of irreplaceable cultural, social, environmental and economic value. Bearing in mind all 
the key development dimensions of cultural heritage, the authors assumed that sustainable tourism, as 'tourism that respects both local people and the traveller, cultural heritage and the environment' could offer the proper models for sustainable management of cultural heritage.

The authors have tried to find the optimal model of cultural heritage management, which would allow sustainable local development in the turbulent global context, using the authentic characteristics of destinations and the unique elements of urban identity to differentiate them from competitors. The proposed hypothesis is that cultural tourism, which 'cares for the culture it consumes while culturing the consumer' (Richards 2007, 1), as a sustainable alternative to mass tourism, could strengthen the identity and economy of the local community, create new jobs, increase the quality of life of local residents and the pleasure of visitors, improve the image and attract investors. Combination of cultural and tourism development policies could act as a catalyst, promoting the local destination as the most desirable and attractive place to live, work, visit and invest in. Investing in cultural heritage can significantly improve the quality of life of local residents and their guests, regenerate neglected urban areas and increase the value of real estates.

The focus of this paper is on the city of Pula, Croatia. As a city of three thousand years of historical continuity, with its urban identity formed in the key periods of the Roman, Venetian and AustroHungarian rule, Pula is today recognizable for the abundance of cultural heritage sites (with Arena as the iconic symbol of the city), industrial and former military heritage, developed cultural industries and festivals, and the nearby Brijuni Islands, a unique cultural landscape and national park.

Military function defined the city's identity for 150 years. Pula was selected for the main Austrian (Austro-Hungarian) naval port in 1850 and then began a period of the most intensive modernization and urbanization, including the major public and infrastructure investments, which gave the city its specific Central European urban identity. At the same time, the nearby Brijuni Islands turned to the most exclusive tourist resort on the Adriatic. Contemporary local residents inherited from this period the most important urban facilities, as well as the well preserved fortification system, which is still waiting for a proper valorisation. Commemoration of the World War I was an opportunity to valorise a common European heritage, by transforming the military architecture into creative spaces for civil initiatives, cultural and scientific cooperation and intercultural 
dialogue. In this paper the authors tried to explore possibilities of valorisation of transnational, multicultural heritage of Pula through cross-border international partnerships in the framework of European projects and programmes. The authors have analysed the most effective European models of good practice, as well as advantages of transnational cooperation in improving capacities for the sustainable use of the city's more valuable assets through heritage tourism.

\section{Valorisation of Cultural Heritage through Sustainable Tourism}

The world in the 21st century is faced with different and severe problems caused by irresponsible use of resources resulting in many environmental, social, economic, cultural, political and other problems with potential long-term and unexpected effects. The dominant linear economic model, i.e. model of depletion of resources through the extraction, production, consumption and disposal is not sustainable any more. There is a need for a transition towards a more conscious and responsible way of satisfying needs based on the model of circular economy, i.e. a model of efficient use of resources.

In the last thirty years the concept of sustainable development is pointed out as a potential driver of that transition. The most citied definition of the concept, although often criticised for its potential ambiguity, is from the report Our Common Future (UNWCED 1987). It was defined as 'development that meets the needs of the present without compromising the ability of the future generations to meet their own needs.' In the same time, it is not 'a fixed state of harmony, but rather a process of change in which the exploitation of resources, the direction of investments, the orientation of technological development, and institutional change are made consistent with future as well as present needs' (UNWCED 1987, 17). The complexity of the concept of sustainable development derives from the fact that its implementation requires changes of behaviour in all segment of human activities, i.e. a fundamental revision and change of the values, thinking and behaviour. It requires the transition from the concept of Homo economics, i.e. a rational creature, selfish and oriented towards the maximisation of utility towards the concept of Homo sustinens, i.e. a human being that lives in harmony with sustainability requirements (Siebenhüner 2000).

Tourism, due to its size and interconnectedness with many parts of the society and the economy, can be a powerful driver towards that change. According to UNW To (2016) in 2015 tourism has realized nearly $10 \%$ of the global GDP, $6 \%$ of global trade, and $11 \%$ of total 
global employment (direct, indirect and induced) reaching a total of 1,184 million travellers.

As Mihalic $(2014,461)$ notes, the debate for a more responsible tourism development has begun in the early 1970s when George Young argued that the impacts of tourism are both a blessing and a blight and Claude Kaspar, called for a new dimension of the tourism debate which he termed environmental ecology. Later, Jost Kripendorf (1999) challenged the sense of mass tourism in his book The Holiday Makers begging the search for alternative forms of tourism development. In 2005, the Unw To $(2013,17)$ has defined sustainable tourism as 'tourism that takes full account of its current and future economic, social and environmental impacts, addressing the needs of visitors, the industry, the environment and host communities.' The concept requires the informed participation of all relevant stakeholders (business, tourists, investors, employees, governments and local community) and consistent political leadership to ensure wide participation and consensus building. But, as Goodwin (2011) notes, sustainable development lacks measurable indicators in order to determine whether or not is being really managed towards sustainability. The concept appears to be operative, but in its implementation it seems to be too abstract, the principles are not applied, the concept is inoperative, the objectives are not achieved, responsibility is not taken.

As Goodwin states, at the core of responsible tourism is the ethic of responsibility, the willingness and capacity to respond, to exercise responsibility. There are three aspects of the concept of responsibility that are particularly relevant to tourism: accountability, i.e. the liability to be called to account for actions and omissions; capability to act or capacity, i.e. capability assumes capacity - responsibility is attributed or accepted because the individual or group had both the opportunity and capacity to act, they have 'responsibility and the capacity to respond or to be responsive, i.e. individuals and organizations are expected to respond and make a difference. The author points out the behaviour - base view involving different stakeholders to dialogue and create more sustainable solutions. Responsible tourism refers to the willingness to take responsibility to respond, to act to contribute to sustainability.

Mihalic (2014), after a detailed sustainable - responsible tourism discourse, has proposed a process towards responsustable tourism through the Triple A Model (figure 1) as a tool that helps to understand the process of how a responsible tourism destination or firm actually implements the sustainability agenda. It can be applied 
FIGURE 1

The Triple-A Model for responsustable tourism (adapted from Mihalic 2014)

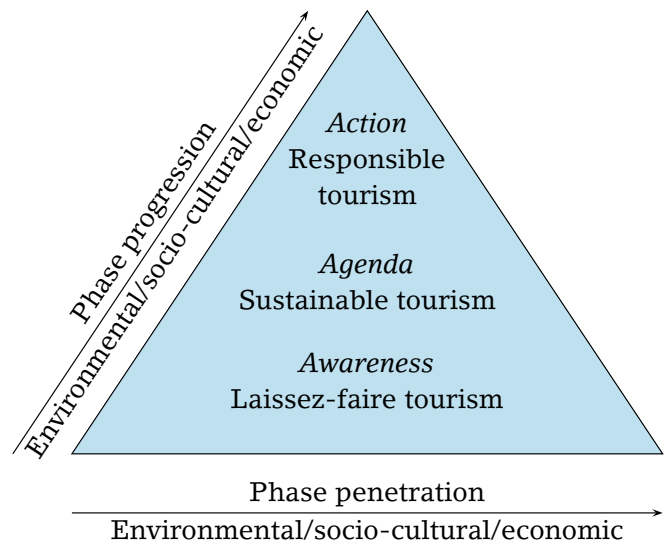

in tourism destination of any level. Different relevant stakeholders have a responsibility to seek to reduce the negative and enhance the positive environmental, socio-cultural and economic impacts of tourism.

The focus of this paper is on valorisation of cultural heritage through sustainable tourism. Namely, the concept of sustainable tourism usually embraces three aspects of sustainability: economic sustainability, i.e. valuation of natural, social and human capital in the accounting processes at the firm, regional or national level as well as internalisation of negative externalities; social sustainability, i.e. creation of conditions of growth of social capital through social cohesion, social justice, respect of cultural identity, honesty, ethics, etc. and environmental sustainability, i.e. responsible use of natural resources and environmental protection.

As Urosevic and Afric Rakitovac note $(2016,375)$, in the un Agenda 21 from 1992, culture was defined as an important segment of social sustainability. But in the last ten years it is being considered also as $\mathrm{s}$ fourth pillar of sustainable development, i.e. as a new, innovative and proactive aspect of sustainable development. The significance of cultural dimension of sustainable development derives also from the fact that cultural factors influence human relations, consumer behaviour, environmental assessment and interaction with it. So, sustainable tourism cannot be culturally neutral, i.e. it has to promote understanding and respecting of cultural particularities, identities, diversity of tourists and stakeholders in the tourism destination.

Cultural heritage usually consists of resources inherited from the past in all forms and aspects - tangible, intangible and digital, including monuments, sites, landscapes, skills, practices, knowledge

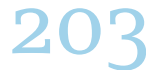


and expressions of human creativity, as well as collections conserved and managed by public and private bodies such as museums, libraries and achieves (European Union 2012).

Cultural heritage, as an integral part of the cultural and creative sector, could have a significant role in the local economy through the development of entrepreneurship in culture, opening of new, diversified jobs, revalorisation of traditional crafts and arts, innovative working methods, etc. Sustainable management of cultural heritage through tourism is a strategic challenge of the 21st century. The expansion of cultural tourism over recent decades has played a crucial role in the promotion and protection of tangible and intangible heritage as well as the development of arts, crafts and creative activities. Aiming to explore and advance new partnership models between tourism and culture, the first UNWTO/UNESCO World Conference on Tourism and Culture was held in Seem Reap, Cambodia in February, 2015. The Conference participants endorsed the Siem Reap Declaration on Tourism and Culture, which underlines that successful outcomes require engaging culture and tourism stakeholders, especially within all levels of government and public administrations, to address cross-cutting responsibilities in areas such as governance, community engagement, innovation and corporate social responsibility. At the local level, each tourism destination should decide how to valorise its cultural heritage through sustainable tourism. It could be realised through smart specialisation strategies.

\section{Sustainable Cultural Heritage Management: \\ A Challenge for Tourism Destinations}

Tourism destinations should awake the importance of cultural heritage and create and implement models of their sustainable revitalisation and management. Sustainable management of cultural heritage is a challenge for the contemporary civilisation in which the key stakeholders are oriented towards maximization of profits regardless the long-term consequences on the quality of life, impact on the environment, preservation of cultural heritage and cultural landscapes. In such, very dynamic conditions, cultural heritage is often threatened, e.g. vanishing of local languages, customs, tradition, devastation of material cultural heritage, etc. Respecting values of cultural heritage and cultural diversities contributes to proper valorisation of heritage and helps the implementation of sustainable tourism at the local level.

The focus of cultural heritage management, in the context of sustainable development, has been redirected from individual heritage 
objects towards the natural and socio-economic environment in which the heritage is situated. Therefore, cultural heritage management in the function of sustainable development requires understanding of specific characteristic of economic development of the observed community, demographic trends, social changes and challenge the community is faced with. As an inclusive model of cultural heritage management, it is necessary to involve in the management process, in a direct and indirect way, various stakeholders: cultural institutions, entrepreneurs, tourism boards, government (at local, regional and national level), NGos, local inhabitants, tourists, etc. Besides, it is important to consider traditional knowledge, values and habits. Due to the complex interdependences and interactions of the stated stakeholders, the design and implementation of a sustainable model of cultural heritage management is a constant challenge (UNESCO 2013, 15).

Cultural heritage management can be defined as the systematic care taken to maintain the values of cultural heritage assets for the enjoyment of present and future generations. The main goal of cultural heritage management is conservation of a representative sample of the tangible and intangible heritage for future generations, but also proper presentation and interpretation of its specific cultural value to present generations, using popular methods to transmit the message about the value of heritage through general educational or awareness building (McKercher and du Cros 43-65, 2009). Recognition of the uniqueness and universal significance of cultural heritage sites could transform them very quickly into attractive tourist destination, allowing effectively greater levels of engagement with the past, collective memories, identity and its meanings outside of purely national and sometimes nationalistic context (Robinson and Picard 2006, 19).

In the context of sustainable development, the fundamental paradigm of heritage management has been changed. As shown by the table 1, cultural heritage shouldn't be set aside for conservation, but it should be protected for its social and economic objectives. Various stakeholders should be involved. Cultural heritage shouldn't be observed as a separate, isolated, 'island,' but as a part of a wider system: not only in the context of national wealth, but also as an asset that belong to the local and world heritage. The management process should be proactive, considering long-term implications. It should involve experts with different skills and respect the knowledge of the local community.

The keystone of sustainable tourism is the participation of the lo- 
TABLE 1 A New Paradigm for Cultural Heritage Management

\begin{tabular}{|c|c|c|}
\hline Topic & $\begin{array}{l}\text { As it was: } \\
\text { Cultural heritage were ... }\end{array}$ & $\begin{array}{l}\text { As it is becoming: } \\
\text { Protected areas are ... }\end{array}$ \\
\hline Objectives & $\begin{array}{l}\text { Set aside for conservation, es- } \\
\text { tablished mainly for its attrac- } \\
\text { tiveness, managed mainly for } \\
\text { visitors and tourists. }\end{array}$ & $\begin{array}{l}\text { Protected also with social and } \\
\text { economic objectives, managed } \\
\text { with local people more in mind. }\end{array}$ \\
\hline Governance & Run by central government. & $\begin{array}{l}\text { Run by partners and involve an } \\
\text { array of stakeholders. }\end{array}$ \\
\hline Local people & $\begin{array}{l}\text { Planned and managed without } \\
\text { considering local opinions. }\end{array}$ & $\begin{array}{l}\text { Run with, for and in some cases } \\
\text { by local people. }\end{array}$ \\
\hline Wider contacts & Managed separately, as 'islands.' & $\begin{array}{l}\text { Planned as a part of national, } \\
\text { regional and international sys- } \\
\text { tems, developed as 'networks.' }\end{array}$ \\
\hline Perceptions & $\begin{array}{l}\text { Viewed primarily as a national } \\
\text { asset, viewed only as a national } \\
\text { concern. }\end{array}$ & $\begin{array}{l}\text { Viewed also as a community as- } \\
\text { set, viewed also as an interna- } \\
\text { tional concern. }\end{array}$ \\
\hline $\begin{array}{l}\text { Management } \\
\text { techniques }\end{array}$ & $\begin{array}{l}\text { Managed strictly within a short } \\
\text { timescale, managed in a techno- } \\
\text { cratic way. }\end{array}$ & $\begin{array}{l}\text { Managed adaptively in a long- } \\
\text { term perspective, managed with } \\
\text { political considerations. }\end{array}$ \\
\hline Finance & Paid for by taxpayer. & Paid for from many sources. \\
\hline $\begin{array}{l}\text { Management } \\
\text { skills }\end{array}$ & $\begin{array}{l}\text { Managed by scientists and ex- } \\
\text { pert specialised in cultural is- } \\
\text { sues, expert led. }\end{array}$ & $\begin{array}{l}\text { Managed by multi-skilled in- } \\
\text { dividuals, drawing on local } \\
\text { knowledge. }\end{array}$ \\
\hline
\end{tabular}

Nотеs Adapted from Phillips (2013).

cal community in the decision-making process. It requires the organisation of awareness campaigns and educational and information programs must first be organized by and for the community, to enable them to formulate their sense of identity. Namely, the heritage of a place is often misinterpreted and neglected by its own residents, who do not help in its maintenance or in its marketing, because there is a lack of previous knowledge and connection with this heritage; consequently, they are not able to enjoy it nor to appreciate it. In order to make this awareness-raising activity sustainable, it must be structured on a long-term, education-for-life basis, allowing a sustainable community to live in harmony and dignity and become more sensitive not just about the heritage value of their own place, but also toward the world around them (De Camargo 2007, 239-55).

It is a challenge to include different stakeholders in a participatory process, i.e. a process directed towards creation of new ways of collaborations in cultural management or empowerment of already existing ways of collaboration. Advising, educating and including stakeholders is a challenging and request time and efforts. There- 
fore, often the obtained outcomes go beyond the invested. Phillis (2013) states practical experiences in different countries which show insufficient involvements of stakeholders in the heritage management process. That can be caused by different reasons: specific characteristics of the management system, unequal power of different stakeholders, political and socio-cultural factors in its surroundings (poverty, social injustice, deeply rooted cultural values, etc.) and insufficient inclusion of marginalised people (women, youth, minorities, people with disabilities, etc.). The participatory process often require readiness for difficult compromises and negotiations and is time demanding.

As Boccardi (2007) notes, cultural heritage management in function of sustainable development can be understood two-fold:

- as a care for heritage preservation, as an aim per se, and as a part of environmental/cultural resources that should be preserved and protected also for future generations (intrinsic value);

- through the potential contribution that heritage, as an important part of the wider social system, can have for the environmental, social and economic dimension of sustainable development (instrumental value).

The selection of the proper approach depend on the specificities of the heritage, i.e. it is possible that in some cases the first criteria will be dominant (e.g. for heritage included on the World Heritage List). Socio-economic impacts are important, but they are not always necessary. In practice, it is desirable the combination of both approaches. Cultural heritage management coherent with the sustainable tourism concept is a demanding and challenging process. Cautious valorisation and revitalisation of cultural heritage contribute to its protection, stimulates economic development, strengthen social capital and environmental protection.

\section{Valorisation of the Common European Heritage through Transnational Networks}

In this paper, the authors use the concept of European heritage, since it offers an innovative perspective on local, regional, national, as well as Europe's transnational history and multicultural heritage (Ashworth and Howard 1999). According to some recent Eu policy documents, 'Europe's cultural heritage is our common wealth - inheritance from previous generations of Europeans and our legacy for those to come. It is an irreplaceable repository of knowledge and a valuable resource for economic growth, employment and social co- 
hesion. It is a source of inspiration for thinkers and artists, and a driver for our cultural and creative industries. Our cultural heritage and the way we preserve and valorise it is a major factor in defining Europe's place in the world and its attractiveness as a place to live, work and visit' (European Commission 2014).

Current challenges facing the European Union, such as the economic and migrant crisis, the rise of extremism, radicalization and populist nationalism and as well as serious violations of the values of freedom, tolerance and democracy on which our common European identity is based call for urgent and coordinated responses. According to the European Cultural Heritage Strategy (in the making), 'cultural heritage, in all its components, is a key factor for the refocusing of our societies on the basis of dialogue between cultures, respect for identities and diversity, and a feeling of belonging to a community of values. Cultural heritage is also a powerful factor in social and economic development through the activities it generates and the policies which underpin it. It constitutes an invaluable resource in the fields of education, employment, tourism and sustainable development' (Council of Europe 2016).

Recent European projects, such as Cultural Heritage Counts for Europe aimed to raise greater awareness on the multiple benefits of cultural heritage and present policy recommendations for tapping into European heritage's full potential.

The European Cultural Heritage Strategy for the 21st century promotes good governance based on participatory management involving national, regional and local levels, but also transnational cooperation in valorising our common heritage. Awareness-raising, capacity-building, interdisciplinary research and training are therefore essential. One of the main goals of the Strategy is to use cultural heritage to transmit the core values of the Council of Europe: democracy, respect for human rights and fundamental freedoms, openness and dialogue, the equal dignity of all persons, mutual respect and sensitivity to diversity, as well as to promote heritage as a meeting place and vehicle for intercultural dialogue, peace and tolerance (Council of Europe 2016, 5-10).

\section{European Models of Good Practice}

Since the authors were interested in the European dimension of the historic urban landscape of Pula, the most effective European models of good practice in sustainable valorisation of a common transnational heritage were analyzed.

European Heritage Label includes sites which have been carefully 
selected for their symbolic value, the role they have played in the European history and activities that bring the European Union and its citizens closer together. The programme was created by the European Commission to celebrate and symbolise European ideals, values, history and integration. It was conceived to promote mutual understanding, European dimension of a common heritage and to communicate $\mathrm{EU}$ values. European Heritage sites bring to life the European narrative and the history behind it, including educational activities, especially for young people.

The other very successful European best practice model is the Council of Europe's Cultural Routes programme, aimed at developing awareness about the European culture through travelling, designing the tourism networks connected to the European cultural geography, and promoting the most important sites and crossroads of the European civilization as interesting places for tourists. The main idea of the project founders was to provide greater visibility and respect for common European identity, and to preserve and promote European cultural heritage in terms of improving life and social, economic and cultural development (Council of Europe 2015). There are already very successful examples of transnational cultural routes, such as Forte Cultura Route of Central European Fortified Heritage (Central Europe Programme 2014) or the cross-border Walk of Peace along the onetime Isonzo Front. There are also very valuable initiatives aimed at developing transnational partnerships in the SEE Region, such as The Roman Emperors Route or Return of Argonauts, or transnational UNESCO nominations (such as nomination of mediaeval tombstones - stećci - as a common multinational and world heritage of $\mathrm{B}$ and $\mathrm{H}$, Croatia, Montenegro and Serbia).

The conducted research indicated also the benefits of the (transnational) World Heritage listing for sustainable heritage tourism. There is a recent initiative for transnational nomination of the Venetian Fortresses on the Adriatic, built between 15th and 17th centuries, to the World Heritage List. The site extends for more than $1.000 \mathrm{~km}$ from the Pre Alps of Lombardy to the Eastern coast of the Adriatic, in the area between the western outpost (Bergamo, Italy) and the Bay of Kotor (Montenegro), including fortifications in Šibenik, Zadar and Korčula in Croatia. There were also recent suggestions of Iсомоs experts to nominate Pula as the former main Austrian naval port with its powerful fortification system to the UNESCO World heritage list, in the framework of the serial transnational nomination of Austro-Hungarian fortifications, because of its outstanding universal value as a part of a common European heritage and a representative 
and commemorative symbol of the common multicultural past in this transnational borderland zone. Experts agree that this unique heritage complex, in the broader Central European context meets three or more criteria for candidacy.

The comparative analysis of European examples of good practice indicated possible models of sustainable management and valorisation of these specific categories of heritage (former military, fortified heritage), which could at the same time enhance the process of urban regeneration and social revitalization. As a good practice example, the authors propose the Seaplane Harbour Museum in Tallinn, where the reconstruction of former seaplane hangars marked the start of transformation of a neglected former military zone in the harbour in the new cultural quarter and the most visited tourist attraction in Estonia. Another example of good practice is the Suomenlinna fortress in Helsinki, a former fortified military base, transformed into a tourist attraction protected by UNESCO and a very popular recreation zone for local people. One of the largest maritime fortress in the world today is revitalized as a unique cultural district. With its 850 permanent inhabitants and 350 people working there, it is not simply a big museum but a living community. The authors believe that this model of transformation and participatory management of the protected fortified heritage, which successfully narrates the multicultural history of Finland and its neighbours through a high quality cultural and tourism offer, is very useful and applicable in the former military zones in Pula and Croatia.

There are also numerous good practice examples of creative cities from Central European countries, but also from the whole SEE region (Hristova et al. 2015), which use their former military and industrial heritage to support culture, creativity and innovation and to build creative districts as innovation centres for sustainable urban growth. Specific regional European programmes and transnational partnerships, such as the INTERREG Central Europe programme, offered new opportunities for cooperation in innovation, transport, culture and infrastructure for sustainable growth. Cultural heritage and creative resources are among the main priorities this programme, aimed to foster transnational cooperation in sustainable management of cultural heritage as well as in development of cultural and creative industries, using culture as a driver for innovation and creativity (Central Europe Programme 2014).

Valuable local cultural resources could be explored also in the framework of the cross-border projects aimed at involving the local community in participatory sustainable heritage management, such 
as the recent project ADRIFORT, which in the framework of the IPA Adriatic Cross Border Cooperation Programme included also the city and the University of Pula, with the aim of creating a new model of transformation of military heritage in the areas promoting civil initiatives, peace and intercultural dialogue.

\section{Developing Heritage Tourism in Pula}

Croatia is a Mediterranean country with a long tradition as a host country. In 2014 it has realized 13.1 million tourists and 66.5 million overnights (Ministarstvo Turizma 2016). According to the World Economic Forum (WEF) Tourism and Travel Competitiveness Index 2015. Croatian tourism is ranked at the 33rd place out of 141 (WEF 2015). Compared to we F Global Competitiveness Index, where Croatian economy is placed at the $77_{\text {th }}$ place out of 144 , tourism, as much better positioned, is considered as one of the most competitive sectors of Croatian economy. According to Schrittwieser $(2014,3)$ Croatia will be recognized as an innovation and creative hub and will be one of the leading south-east European knowledge-based countries embracing creativity and innovation at all levels of society. The following cross-sectoral inter-multi- and trans-disciplinary topics have been identified: Кет, Іст, Tourism, Creative and cultural industry, Green growth and Social challenges.

The focus of this paper is on the city of Pula and on its main resources for sustainable heritage tourism. The analysis of the monograph Puna je Pula (Pula is Crowded) by the Istrian scientist and polyhistor Mate Balota (2015) shows that the key developmental periods, which formed Pula's urban identity, were the periods of Roman and Austro-Hungarian rule, and the period after World War II, when the industrial and military city turned into a regional cultural and tourist centre. As Balota noted: 'Life in the Gulf of Pula flourished only in large frames and with a large background. So, the rise and fall of the Pula city emerges as a result of the use and misuse of the Pula Bay ... The Pula bay is too big to be maintained and used by the city. Until the Austria selected Pula for the main naval port, the Pula's harbour was mostly empty for 20 centuries. It took much more power and much stronger interests from local and regional not only to protect the city, but also to valorise and develop all its potential [...]' (Balota 2005, 9-10).

Pula is today a city with a uniquely Central European, coastal atmosphere, but it nevertheless owes most of its urban identity to a few key monuments from the classical period, when the Roman colony was founded, in the mid-1st century вс: the Roman Amphitheatre, 
the Temple of Augustus in the Roman Forum, the Arch of the Sergii. The heritage of the classical antiquity is what makes Pula a typical Mediterranean city. Not as much is known about the impressive heritage of the Austro-Hungarian Monarchy. After being selected as the main Austrian naval port in 1850, in only 50 years Pula was transformed from a deserted village with 900 inhabitants into a multicultural European metropolis, and its population increased as much as 50 times! The well preserved fortification system from this period, unique in Europe, is still awaiting proper valorisation.

The city still insufficiently uses the potential of its rich multicultural history and preserved heritage and the fact that it is located in a characteristic borderland zone where different cultures and identities have continually met and negotiated through history. A rich cultural and historical heritage as a base for attracting tourists and investors requires appropriate approaches to restoration, revitalization and protection. While the protection of ancient monuments has been systematically regulated under programmes of the Ministry of Culture, the architecture of the Austro-Hungarian and later periods is still waiting proper heritage management programmes. The most challenging situation is certainly in the neglected historic urban core, which as a dynamic public space with 3,000 years of historic continuity has the largest development potential. Therefore, the right policies of urban revitalization and regeneration of the historic centre, to restore life and vitality to neglected urban tissue, will be of great importance in the future.

The proposed swот analysis presented in table 2 confirms huge development potentials of cultural tourism in the city of Pula. To develop competitive products on the base of a distinctive urban identity, it is necessary to identify the unique characteristics of the destination as well as the elements of a common European heritage. This means that planning priorities have to be investing in the main cultural resources, such as the historic urban core, valorisation of the former military zone and the fortification system for different cultural, tourism and scientific purposes, extending the season through integration of attractions in events and cultural routes and design of new integrated cross-border projects through transnational partnerships.

\section{Conclusion}

Presented research indicates great development potential of cultural tourism in the city of Pula. The authors showed that cultural heritage could also act as a catalyst of sustainable development, bringing en- 
TABLe 2 Swot Analysis: Cultural Tourism Development Potential of Pula

\begin{tabular}{|c|c|}
\hline $\begin{array}{l}\text { Strengths } \\
\text { The richness and diversity of cultural } \\
\text { heritage, 'eventful' and creative city, } \\
\text { multicultural history, advantageous geo- } \\
\text { graphical position, proximity to emissive } \\
\text { markets, local distinctiveness, cultural } \\
\text { identity of the city, belonging to Mediter- } \\
\text { ranean and the central European cul- } \\
\text { tural circle, the beauty of nature and the } \\
\text { sea, pleasant climate, human capital, } \\
\text { strong alternative scene and civil society. }\end{array}$ & $\begin{array}{l}\text { Weaknesses } \\
\text { Poor management of resources, ne- } \\
\text { glected old city centre, lack of programs } \\
\text { of urban regeneration, traffic and in- } \\
\text { frastructure problems, devastated for- } \\
\text { mer military zones, industry in the city } \\
\text { centre, unused port, insufficient aware- } \\
\text { ness of the heritage potential, insuffi- } \\
\text { cient intersectoral cooperation, lack of } \\
\text { cultural managers, extreme seasonal- } \\
\text { ity, inadequate communication strate- } \\
\text { gies, lack of facilities for entertainment, } \\
\text { unrecognized and undeveloped cultural } \\
\text { tourism product, undefined image of the } \\
\text { city in the global market, lack of invest- } \\
\text { ments, communication problems be- } \\
\text { tween stakeholders, inadequate coordi- } \\
\text { nation and networking of programmes } \\
\text { and institutions. }\end{array}$ \\
\hline $\begin{array}{l}\text { Opportunities } \\
\text { International and cross-border coopera- } \\
\text { tion, financing from EU funds, network- } \\
\text { ing of cultural project and programmes, } \\
\text { clustering in cultural and creative quar- } \\
\text { ters, use of new ICT, UNESCO world her- } \\
\text { itage listing, development of cultural } \\
\text { tourism, creating new jobs, investing } \\
\text { in scientific research, capacity building } \\
\text { and awareness-raising about the value } \\
\text { and multiple benefits of investing in } \\
\text { heritage. }\end{array}$ & $\begin{array}{l}\text { Threats } \\
\text { Global recession, sharp competition of } \\
\text { European heritage cities, further devas- } \\
\text { tation of the natural and cultural, attrac- } \\
\text { tion basis, environmental and infras- } \\
\text { tructure problems, changes in the global } \\
\text { market, budget cuts for culture. }\end{array}$ \\
\hline
\end{tabular}

vironmental, economic, social and cultural benefits to the local community. If sustainable development allows local communities to meet the needs of the present without compromising the ability of future generations to meet their own needs, the great challenge for heritage management stakeholders becomes how to integrate cultural heritage and tourism management needs in a process that will result in a product that is appealing to visitors, while at the same time conserving cultural and heritage values. Sustainable cultural tourism can be seen as one of the best ways to address society and its sustainable development, as an opportunity for society to become aware of itself, not only paving the way for economic development, but also for rethinking itself, while turning heritage management and tourism into an arena for debate and civic participation. 
In this paper the authors tried to explore possibilities of valorisation of transnational, multicultural heritage of Pula through crossborder regional partnerships. The conducted research indicated advantages of transnational cooperation, using suggested European models of good practice in improving capacities for the sustainable use of the city's most valuable assets: the oldest historic city core on the eastern coast of the Adriatic and specific cultural resources such as the Roman monuments including Amphitheatre, the Brijuni Islands National Park and the legacy of the former Austria's main naval port with its powerful fortification system.

\section{References}

Ashworth, G., and P. Howard. 1999. European Heritage, Planning and Management. Bristol: Intellect.

Balota, M. 2005. Puna je Pula. Pula: Amforapress.

Boccardi, G. 2007. 'World Heritage and Sustainability: Concern for Social, Economic and Environmental Aspects within the Policies and Processes of the World Heritage Convention.' MSc dissertation, UCL Bartlett School of the Built Environment, London.

Council of Europe. 2015. Cultural Routes Management: From Theory to Practice. Strasbourg: Council of Europe.

- 2016. 'Draft European Cultural Heritage Strategy for the 21th Century.' http://www.coe.int/t/dg4/cultureheritage/CDCPP/Plenary/ 5meeting/CDCPP-2016-10-Final\%2oproject_Strategy\%2021_EN.pdf

De Camargo, P. 2007. 'Using Tourist Resources As Tools for Teaching and Creating Awareness of Heritage in a Local Community.' In Cultural Tourism: Global and Local Perspectives, edited by G. Richards, 239-56. New York: Haworth Hospitality Press.

Central Europe Programme. 2014. Project Stories from the Central Europe Programme: Cultural Heritage and Creative Resources. Vienna: Central Europe Programme.

European Commission. 2014. 'Towards an Integrated Approach to Cultural Heritage for Europe.' сом (2014) 477 final. European Commission, Brussels.

European Union. 2012. 'How Can Cultural and Creative Industries Contribute to Economic Transformation through Smart Specialisation?' http://s3platform.jrc.ec.europa.eu/documents/20182/84453/120420 _CCI_Policy_Handbook_(FINAL).pdf

Goodwin, H. 2011. Taking Responsibility for Tourism. Oxford: Goodfwellow.

Hristova, S., M. Dragićević Šešić, and N. Duxbury. 2015. Culture and Sustainability in European Cities: Imagining Europolis. London: Routledge.

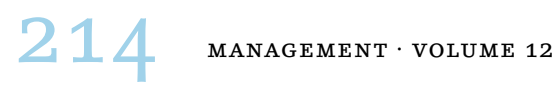


Krippendorf, J. 1999. The Holiday Makers: Understanding the Impact of Leisure and Travel. Oxford: Butterworth-Heinemann.

McKercher, B., and H. du Cros. 2009. Cultural Tourism: The Partnership Between Tourism and Cultural Heritage Management. London: Routledge.

Mihalic, T. 2014. 'Sustainable-Responsible Tourism Discourse - Towards "Responsustable" Tourism.' Journal of Cleaner Production 111 (B): 461-70.

Ministarstvo Turizma. 2016. 'Turistički promet u prosincu 2015. godine.' http://www.mint.hr/UserDocsImages/015_160407_XII.pdf

Phillips, A. 2003. 'Turning Ideas on Their Head: The New Paradigm for Protected areas.' The George Wright Forum 20 (2): 8-32.

Richards, G., ed. 2007. Cultural Tourism: Global and Local Perspectives. New York: Haworth.

Robinson, M., and D. Picard, D. 2006. Tourism, Culture and Sustainable Development. Paris: Unesco.

Schrittwieser, W. 2016. 'Analysis of Smart Specialization Strategies in selected Mediterranean Coastal Regions and Countries.' https:// creativemedit.files.wordpress.com/2014/10/analysis-of-smart -specialization-strategies-in-selected-mediterranean-coastal -regions-and-countries.pdf

Siebenhüner, B. 2000. 'Homo Sustinens: Towards a New Conception of Humans for the Science of Sustainability.' Ecological Economics 32 (1): 15-25.

UnesCo. 2013. Managing Cultural World Heritage. Paris: unEsco.

UNWCED. 1987. 'Report of the World Commission on Environment and Development: Our Common Future.' http://www.un-documents.net /our-common-future.pdf

unwто. 2013. Sustainable Tourism for Development. Madrid: World Tourism Organisation. http://cf.cdn.unwto.org/sites/all/files/docpdf /devcoengfinal.pdf

- 2016. unw to Annual Report 2015. Madrid: World Tourism Organisation. http://cf.cdn.unwto.org/sites/all/files/pdf/annual_report _2015_lr.pdf

Urošević, N., and K. Afrić Rakitovac. 2016. 'Measuring the Multidimensional Role of Culture in Sustainable Development.' Paper presented at the conference European Union Future Perspectives: Innovation, Entrepreneurship and Economic Policy, Pula, 21-3 May.

WEF. 2016. The Travel \& Tourism Competitiveness Report 2016. Geneva: World Economic Forum. 